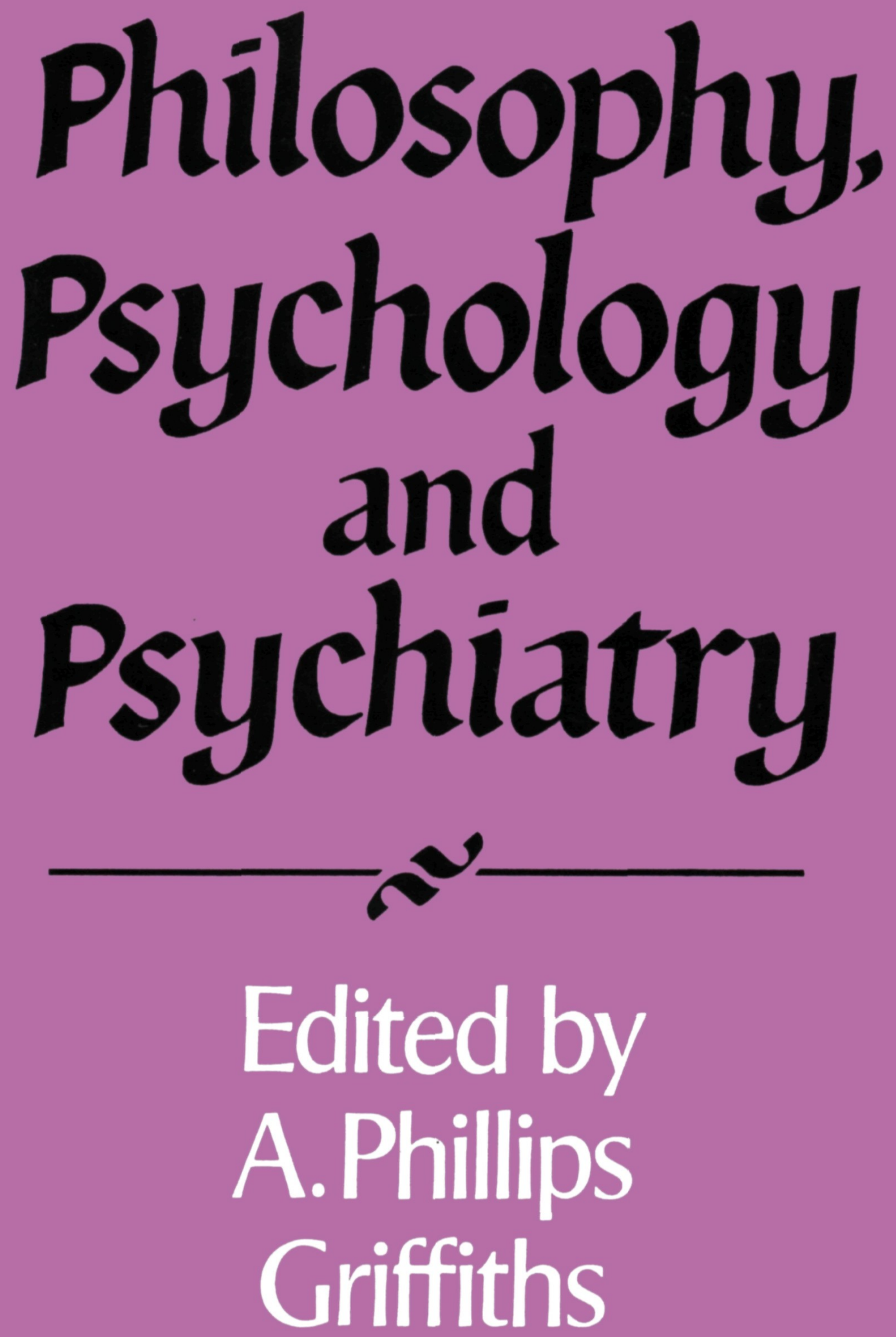




\title{
Philosophy, \\ Psychology and Psychiatry
}

ROYAL INSTITUTE OF PHILOSOPHY SUPPLEMENT: 37

\author{
EDITED BY \\ A. Phillips Griffiths
}


Published by the Press Syndicate of the University of Cambridge The Pitt Building, Trumpington Street, Cambridge, CB2 1RP 40 West 20th Street, New York, NY 10011-4211, USA 10 Stamford Road, Oakleigh, Melbourne 3166, Australia

(C) The Royal Institute of Philosophy and the contributors 1994

A catalogue record for this book is available from the British Library

\section{Library of Congress Cataloguing in Publication Data}

Philosophy, Psychology and Psychiatry/edited by A. Phillips Griffiths

p. cm.-(Royal Institute of Philosophy supplement: 37) Includes bibliographical references.

ISBN 0521469023 (paperback)

1. Psychiatry-Philosophy. 2. Psychology and philosophy.

3. Psychiatry-Moral and ethical aspects. I. Griffiths, A. Phillips. II. Series.

RC437.5.P439 1995

$616.89^{\prime} .001-\mathrm{dc} 20$

ISBN 0521469023 (paperback)

Transferred to digital printing 2000 


\section{Contents}

Preface v

Introduction: Just Getting Started 1 K. W. M. FULFORD

Mind and Madness: New Directions in the Philosophy of Psychiatry

K. W. M. FULFORD

Emotion and Memory: The Second Cognitive Revolution ROM HARRÉ

Meaning and Mechanism in Psychotherapy and General

Psychiatry

JEREMY HOLMES

Making Sense on the Boundaries: On Moving Between

Philosophy and Psychotherapy JOHN SHOTTER

Mental Disorder, Illness and Biological Disfunction DAVID PAPINEAU

Integrity, Boundary and the Ecology of Personal Processes PETER BINNS

Multiple Personality and Computational Models MARGARET A. BODEN

Psychology and Politics: Lies, Damned Lies and Self-Deception

K. V. WILKES

Personal Identity and Psychiatric Illness

TONY HOPE

Vices and the Self

GABRIELE TAYLOR

Wild Beasts and Idle Humours: Legal Insanity and the Finding of Fault

DANIEL N. ROBINSON 


\section{Contents}

Dangerousness and Mental Disorder NIGEL WALKER

Problems with the Doctrine of Consent

J. A. DEVEREUX

Homosexuality

ANTHONY QUINTON

Nietzsche and Music

ANTHONY STORR

References

Notes on Contributors 